\title{
水溶性高分子の物理化学的特性に基づくがんのセラノスティックス薬剤の創製
}

\author{
佐 野紘平
}

\section{Development of Cancer-targeted Theranostics Probes Based on the Physicochemical Properties of Water-soluble Macromolecules}

\author{
Kohei Sano \\ Laboratory of Biophysical Chemistry, Kobe Pharmaceutical University; \\ 4-19-1 Motoyama Kitamachi, Higashinada-ku, Kobe 658-8558, Japan.
}

(Received September 17, 2019)

\begin{abstract}
Water-soluble macromolecules, such as polymers and monoclonal antibodies, have some advantages, including high water solubility, high biocompatibility, a wide range of molecular weights, and amenability to easy modification through the terminal attachment of functional groups. Although there are many instances in which water-soluble polymers are used as solubilizers and stabilizing agents in the medical sciences, the possibility of water-soluble polymers themselves serving as drug carriers in cancer-targeting theranostics (therapeutic + diagnostic) remains to be elucidated. We developed water-soluble polymers labeled with radioisotopes and fluorescence dyes, and elucidated their usefulness as cancer-targeting imaging probes by evaluating their biodistribution with in vivo molecular imaging techniques including nuclear medicine, fluorescence imaging, and photoacoustic imaging. Many water-soluble polymers have some physicochemical properties, such as lower critical solution temperature (LCST), which must be considered as well. We developed cancer-targeting therapeutic compounds by controlling the tumor accumulation of water-soluble polymers based on these physicochemical properties. In this paper, details of the development of cancer-targeting theranostics probes will be discussed.
\end{abstract}

Key words_— water-soluble polymer; theranostics; cancer; drug delivery system

\section{1.はじめに}

まず，治療と診断の融合を意味するセラノス ティックス（therapeutics + diagnostics）について 簡単に説明する。一般に，効率よくがんの治療を実 施するためには, 術前の高精度な診断が必須となる が，単純にがんを発見し，手術により摘出すること がベストな方法であるというわけではない。言わず もがな，良性悪性の鑑別結果など，状況次第で治療 方針は大きく異なる。近年，生体内で起きている病 態に係わる分子プロセスを画像として捉え, 病態を 生きたままの状態で明らかとする技術である “生体 分子イメージング，の研究分野が大きな発展を遂 げ，病変部位の画像化による病因の解明研究，創薬 研究, 臨床診断などの医学研究へ応用されるに至つ

神戸薬科大学薬品物理化学研究室（干658-8558 神戸市 東灘区本山北町 4-19-1)

e-mail: ksano@kobepharma-u.ac.jp

本総説は, 2019 年度日本薬学会奨励賞の受賞を記念し

て記述したものである.
ている。しかしながら，高精度ながんの診断技術 （診断法）が構築できたとしても，それが有効なが ん治療に結びついているかというと疑問が残る.

セラノスティックスは, 診断から得られた情報を いかに治療に結びつけるかに重点をおいた学問領域 として近年大きな注目を集めている.1）ここで，ポ ジトロン断層撮像 (positron emission tomography; PET） やシングルフォトン断層撮像（single photon emission computed tomography; SPECT) を利用す る核医学分野においては，はるか昔からセラノス ティックスの概念が存在している。 すなわち，核医 学診断には放射性医薬品の投与が必要となるが，例 えば，甲状腺がんのがん細胞がヨウ素を取り込む性 質を利用し， $\gamma$ 線放出核種であるヨウ素-123を用い た SPECT 診断がなされる。この診断で，甲状腺が んへの一定の放射能集積が認められた場合, 細胞傷 害性を有する $\beta^{-}$線放出核種であるヨウ素-131（ヨ ウ化ナトリウムカプセル）を投与する治療が実施さ れる。診断から治療へとシームレスかつ極めて効率 
よく展開することのできるセラノスティックスの典 型例と言える。この核医学の例のように，診断と （ほぼ）同一の薬剂を用いて治療を実施すれば，診 断情報に基づく治療，すなわち，診断による治療効 果予測だけでなく副作用評価も可能となり，効果的 な個別化医療へと展開できるものと考えられる．ま た，セラノスティックスの形態は様々であり，例え ば，高精度な外科的手術を行うために術者を視覚的 にサポートし得るプローブ開発や抗がん剂の治療効 果判定に資するプローブ開発などが実施されてい る．筆者は，がんのセラノスティックスに資する薬 剂開発が臨床的に有効であると考え，これまで一貫 した研究を実施しており，本稿ではそれらの成果に ついて詳述する。

\section{2. 水溶性高分子}

筆者は，がんのセラノスティックスに資する薬剤 開発を行うにあたり，タンパク質や水溶性ポリマー などの水溶性高分子を母体化合物として利用するこ ととした．水溶性高分子は，高い水溶性や生体適合 性，広範囲の分子量を利用できる利便性，官能基の 導入を可能とする修飾簡便性などの利点を有してい る。また，ある程度の低分子診断薬あるいは治療薬 を化学的に導入しても，その物性に大きな影響を与 えないと考えられることから，ほぼ同等の物理化学 的特性を持つ診断・治療薬を開発することが可能で ある。

特にポリエチレングリコール（polyethylene glycol；PEG）に代表される水溶性ポリマーについ ては，不溶性タンパク質の可溶化剂として機能する こと, 免疫細胞の食食や生体内䤉素の認識を回避で きる特徵を有すること，などが明らかとされ，現在 では低分子化抗体などの医薬品の可溶化剂や安定化 剤として利用されている。 また，ナノ粒子製剤の表 面を水溶性ポリマーでコーティングすることで，肝 臓や脾蔵などの細網内皮系への取り込みが抑制さ れ，血中滞留性を改善し得るため，薬物の体内動態 制御の観点からも非常に重要な役割を果たすことが 広く知られている。しかしながら，臨床でこれほど の使用実績があるにもかかわらず，それ自体が病変 部位に集積性を示すドラッグデリバリーシステム (drug delivery system; DDS) キャリアとなり得るか 否かについては全く情報がなかった。筆者らは， PEG, ${ }^{2)}$ ポリオキサゾリン (polyoxazoline; POZ), ${ }^{3)}$ ポリサルコシン（polysarcosine; PSar), ${ }^{4)}$ ヒト血清 アルブミン ${ }^{5)}$ につて放射性標識体あるいは蛍光標 識体を合成し，がん組織の血管内皮細胞間の開口部 からがん部位へと送達する enhanced permeability and retention（EPR）効果に基づくがん集積の可能 性について，核医学イメージング及び光音響イメー ジングの手法を用いて評価を行った。まずは，タン パク質及び水溶性ポリマーを用いた分子イメージン グプローブについての研究成果を述べる.

\section{3. プローブ開発}

3-1. ヒト血清アルブミン及び水溶性ポリマーを 母体とする分子イメージングプローブの開発＼cjkstart主 にEPR 効果によるがん集積性を狙い, 臨床応用も 見据えて，生体適合性の高い水溶性高分子としてヒ 卜血清アルブミンやPEG，PSar，POZ の放射性標 識体及び近赤外蛍光色素であるインドシアニング リーン（indocyanine green; ICG）を結合させた蛍 光標識体を合成し，SPECT 及び光音響イメージン グによる評価を行つた. ${ }^{2-5)}$ なお，光音響イメージ ング法は，生体組織透過性に優れる近赤外領域の光 により励起された光吸収体から生じる音響波（超音 波）を検出するもので，光を照射し，光を検出する 蛍光イメージング法に比して，体深部の撮像を可能 とする体外診断及び術中診断法としての展開が注目 されている. ${ }^{6,7)}$ 結果として, Fig. 1 に示すように, いずれのプローブもがん部位のイメージングに成功 した。しかしながら，いずれも血中滞留時間が長い ため血液からの信号がノイズとなり，診断までには 投与後数日以上の長時間を要することを認めたこと から，EPR 効果とは異なる機序で，プローブをが ん組織へ集積させる手法の構築が希求された.

3-2. モノクローナル抗体を基盤とする分子プ ローブを利用する新たな分子イメージング法の構築 そこで筆者は，よりがん特異的な診断を達成する

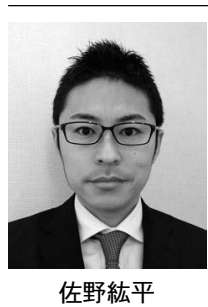

京都府出身. 2009 年京都大学大学院薬 学研究科博士後期課程を修了し, 博士 (薬学) 取得. 九州大学大学院薬学研究 院助教, 京都大学大学院薬学研究科特 定助教, 米国国立がん研究所/米国国立 衛生研究所ポスドク, 京都大学医学部 附属病院助教を経て，2016 年より神戸 薬科大学講師 (現職)。専門は生体分子 イメージング・がんのセラノスティク ス. 


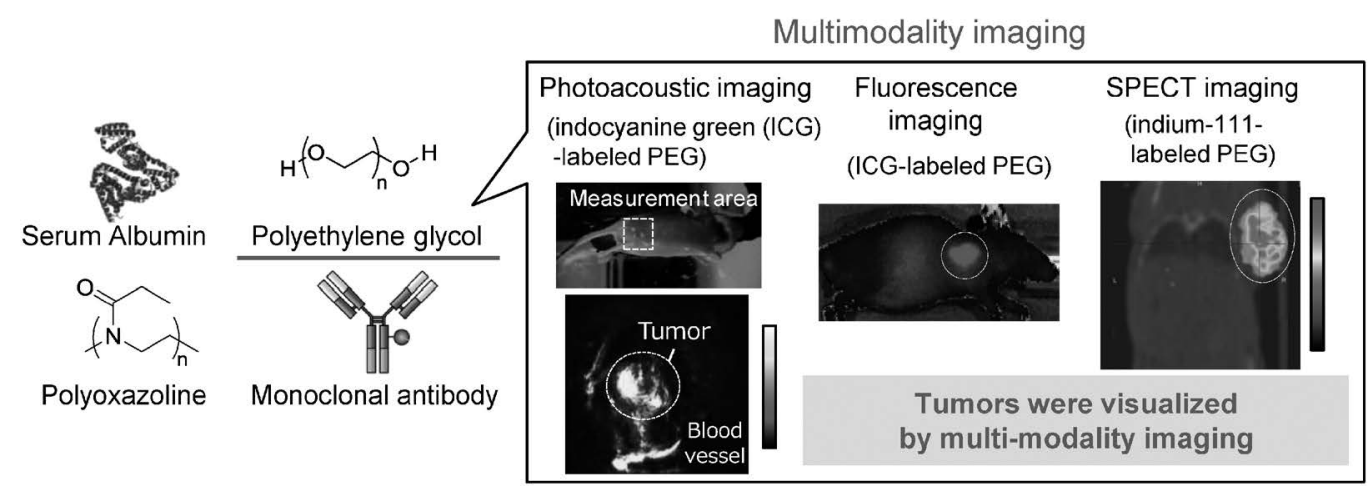

Fig. 1. Multimodality Imaging of Tumors Using Water-soluble Macromolecules Labeled with Fluorescence Dyes and Radioisotopes

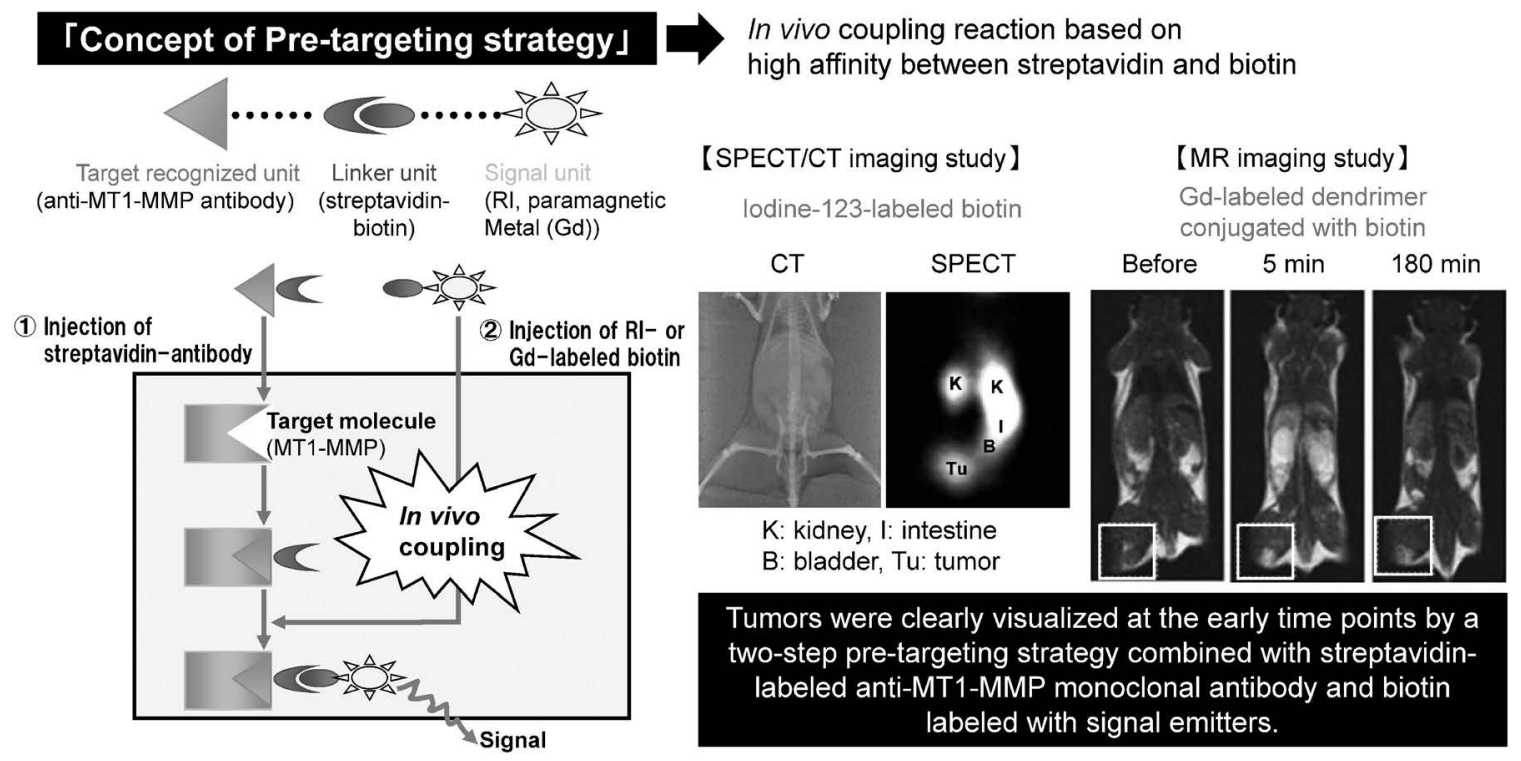

Fig. 2. In Vivo Molecular Imaging Based on Two-step Pre-targeting Strategy

ために，がん特異的抗体 [抗膜型マトリックスメタ ロプロテアーゼ 1 (membrane type 1 matrix metalloproteinase; MT1-MMP) 抗体］を母体とする分子 プローブの開発研究を進めた. ${ }^{8)}$ しかしながら，放 射性標識（ ${ }^{99 \mathrm{~m}} \mathrm{Tc}$ 標識）抗体を用いた検討では，上 述のヒト血清アルブミンなどと同様に，至適な撮像 までのタイミングに長時間を要したことから，ビオ チンとストレプトアビジンの高い親和性及び特異性 に着目し，プレターゲティング法に基づく撮像法を 考案した. 9,10)すなわち, Fig. 2 に示すように, 一 段階目としてストレプトアビジンを結合させた抗体 （抗 MT1-MMP 抗体）を投与し，それが標的分子 (MT1-MMP) に特異的に結合した後に，二段階目 として放射性ヨウ素標識ビオチンあるいは常磁性金 属（ガドリニウム）結合ビオチンを投与した，第二
段階で投与するプローブは，ストレプトアビジンと ビオチンの高い結合親和性によるインビボカップリ ング反応を起こして病変部位に集積する一方で，非 標的部位からの速やかなクリアランスが期待される ため, 投与後早期からのイメージングが可能になる と考えた．なお，MR 造影剤としては，ガドリニウ ムを水溶性高分子であるデンドリマーに複数結合さ せることで, 感度の指標となるプロトン緩和能の改 善を図った。実際, プレターゲティング法を利用し た場合，放射性標識抗体を用いた場合と比較して腫 瘍対血液比は有意に改善されるとともに，イメージ ング実験を実施したところ，SPECT/CT イメージ ング及び MRI にてがんを明瞭に描出することに成 功した。 これより，生体イメージングへ抗体の利用 を可能とする新しい分子プローブ設計法を構築でき 


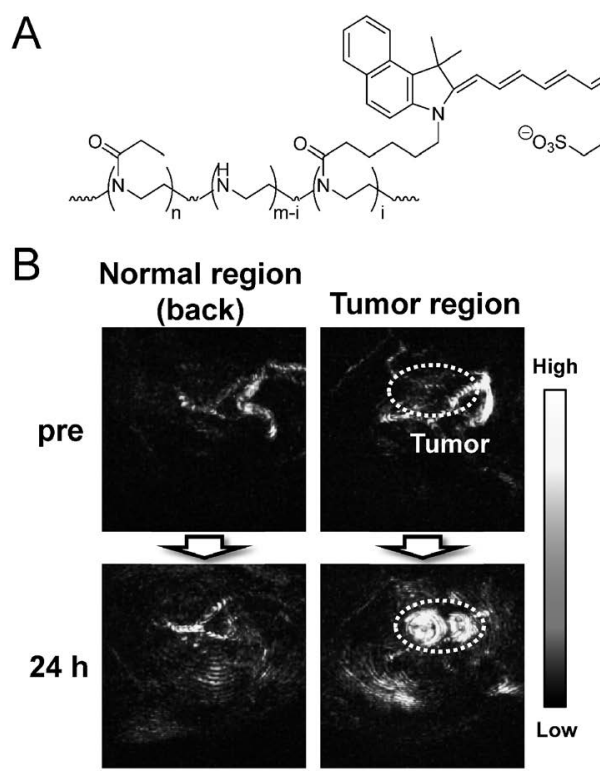

ICG-POZ

(50 kDa, 5\%, D/P=8)

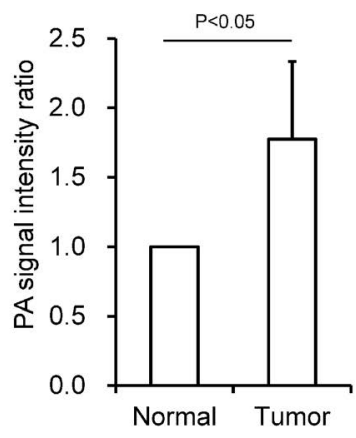

Fig. 3. Photoacoustic Tumor Imaging Using ICG-labeled Polyoxazoline

(A) Chemical structure of ICG-POZ. (B) Photoacoustic imaging of tumors and normal region (back) before and $24 \mathrm{~h}$ after injection of ICG-POZ. The graph shows ratio of photoacoustic signal intensity between normal regions and tumor regions.

たと考えられた。

3-3. 水溶性ポリマーの物理化学的特性（化学的 修飾）を駆使したセラノスティックス薬剤の創製

3-1. で紹介したように, PEG はがん組織へと高 く集積した一方で, PEG は ICG を末端に 1 分子し か結合できないことから感度がまだ十分でないこ と，また，血中滞留時間が長いため血液からの信号 がノイズとなり得るといつた課題があることを見い 出した. ${ }^{2)}$ そこで，筆者は PEG と同程度の安全性 を有し， 1 分子当たりに ICG を多く導入すること が可能な水溶性ポリマーである POZ に着目して, $\mathrm{POZ}$ を分子プローブの母体として選択し (Fig. 3), ICG との結合体（POZ-ICG）を合成，その有効性 を評価した. ${ }^{3)}$ まず，担がんマウスを用いて体内分 布に対する POZ の分子量の影響を評価した結果, 分子量の増大に伴う腫瘍集積性の増加及び血中滞留 時間の延長を認めた。次に, $\mathrm{POZ}$ の側鎖を種々の 割合で加水分解した POZ-ICG では, 加水分解割合 の増加に伴い腫瘍集積は低下することを認めた。ま た，POZ に複数の ICG を結合させた場合，一定数 以上の ICG が結合すると腫瘍集積は低下すること を認めた. その結果, 分子量 $50 \mathrm{kDa}$ かつ加水分解 割合 $5 \%$ の POZ-ICG（ICG/POZ=8）が，良好な 腫瘍集積量及び腫瘍血液比を示すことを見い出し た。さらに，これを用いた光音響イメージングで,
腫瘍部位選択的な信号の増加を認め，またその増加 は投与量並びに腫瘍集積量依存的であった。これに より，開発した POZ-ICG は，先に検討していた PEG を母体とするプローブと比較して，画像コン トラストを大きく改善することを見い出した．さら に興味深いことに，ポリマーに複数の ICG を導入 することで，ICG 濃度あたりの光音響シグナルが 増強する現象を見い出し，これは励起エネルギーを 高効率で光音響シグナルに変換し得るメカニズムと して，今後の光音響プローブ開発に有用な知見とな ることを明らかとした（メカニズムの詳細について は現在検討を進めている)。以上より，POZに対し て複数の ICG 分子を導入した POZ-ICG が，がん の高感度光音響イメージングプローブとして有効で ある可能性を初めて見い出した.

3-4. 水溶性ポリマーの物理化学的特性（下限臨 界溶液温度）を駆使したセラノスティックス薬剤の 創製』さらに筆者は，水溶性ポリマーの下限臨界 溶液温度 (lower critical solution temperature; LCST) をがん組織への薬物送達に活かすことを考えた。水 溶性ポリマーである POZ は，先に述べた PEG と は異なり，その組成や分子量に応じて緻密に LCST をコントロールできることが報告されている. ${ }^{11)}$ そ こで，POZ の放射性標識体を用いる内用放射線療 法への展開を着想し，放射性標識 POZ と温熱療法 

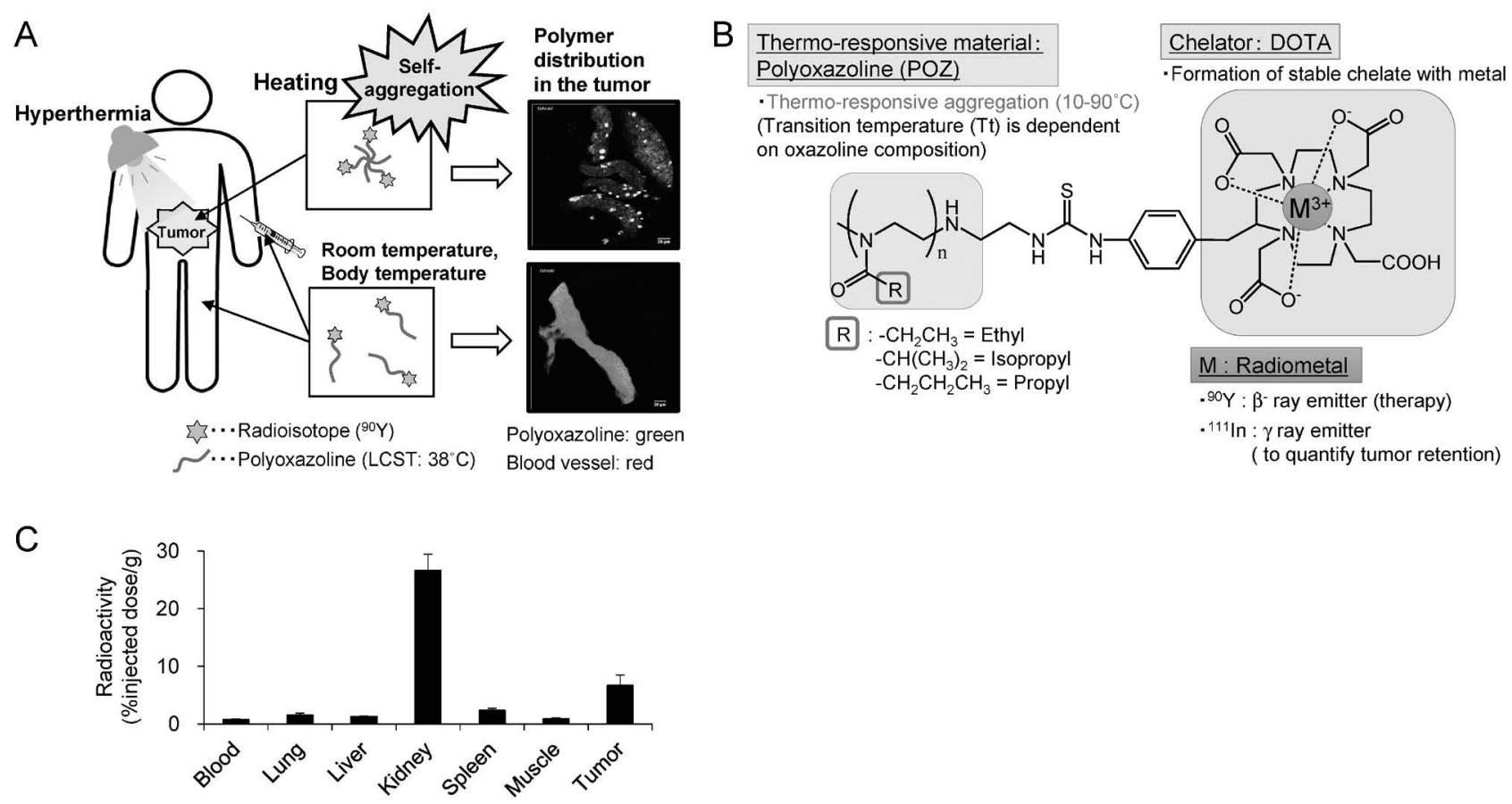

Fig. 4. Cancer Theranostics Using Radiolabeled Thermoresponsive Polyoxazoline (LCST: $38^{\circ} \mathrm{C}$ ) Combined with Hyperthermia of Tumors

(A) Concept of cancer theranostics. Under hyperthermia, the radiolabeled POZ can be self-aggregated in the tumors nearby blood vessels. (B) Chemical structure of radiolabeled POZ. (C) Biodistribution of radiolabeled POZ under hyperthermia of tumors. The tumor-specific accumulation of radiolabeled POZ (except kidney) was demonstrated.

の組合せにより，薬剤をがんへ効率的に送達し得る 新たな DDS の構築を目指した [Fig. 4(A)]. ${ }^{12)}$ す なわち，体温（約 $36.5^{\circ} \mathrm{C}$ ) 以上かつ温熱療法適用 温度（42-43 $\left.{ }^{\circ} \mathrm{C}\right)$ 以下の LCST を持つ POZ 誘導体 及びその放射性標識体 [Fig. 4(B)］を合成し，が ん集積性を評価した。その結果，至適な条件におい て，非加温時と比較してがん集積性が約 2 倍向上 し，正常組織と比較しても 2-3 倍の高いがん特異的 な集積を認めた [Fig. 4(C)]。また，その集積には $\mathrm{POZ}$ の凝集効果が関与していることを，インビボ 共焦点蛍光顕微鏡を用いて明らかにした $[\mathrm{Fig} .4$ (A)]。これにより，薬剤のがんへの集積性を“診 る”ことに成功した. さらに, 最近の研究において, $\beta^{-}$線放出核種で標識したプローブの投与とがん部 位の加温処置を組み合わせることにより，高いがん 治療効果が得られている。この手法は副作用を低減 し，治療効果を高め得る新たながん治療ストラテジ となるものと期待される.さらに別研究において, $\mathrm{POZ}$ の分子内に様々な機能性分子を化学的に修飾 する方法を構築していることから, ${ }^{3,13)}$ 今後 POZに がん標的認識ユニットを導入するなど，がんへの薬 物送達量をより向上させる手法を構築できるものと
考えている.

\section{4. おわりに}

本研究では, 水溶性ポリマーやタンパク質（抗 体，血清アルブミン）などの水溶性高分子をキャリ アとするがんのセラノスティックス薬剤の開発につ いての研究成果を述べた。筆者は，まず，これまで にほとんど評価されてこなかった水溶性ポリマーの 薬物キャリアとしての可能性を見い出すとともに, 物理化学的な手法を駆使して，それらのがん集積性 を制御（増強）することで，それを高精度ながん診 断（Diagnostics）に適用し，さらにはその成果を 基盤としたがん治療（Therapeutics）［セラノス ティクス (Theranostics) 研究] へと展開してきた. これまで分断されることの多かった “診断” と“治 療”の領域をうまく融合し，より効果的な治療へつ なげていくことが期待される。 また，水溶性ポリ マーの物理化学的特性に基づくがんのセラノス ティックス薬剤の開発を進める中で，近年，がん組 織へ能動的に集積し得るポリマー（PSar）の存在 を見い出すなど，水溶性ポリマーは次世代型 DDS キャリアとして幅広く展開できるものと期待してい る，今後，水溶性ポリマーを基盤とするポリマー薬 
学の研究領域を新たに開拓していきたいと考えてい る.

\section{謝辞本研究の大部分は, 京都大学大学院薬学} 研究科病態機能分析学分野にて行われた研究の成果 であり，終始稂篤なるご指導とご鞭撻を賜りました 京都大学大学院薬学研究科病態機能分析学分野 佐 治英郎特任教授に東心より深甚なる謝意を表しま す。また，稂切なるご指導とご教示を頂きました， 京都大学大学院薬学研究科 小野正博教授, 北海道 大学アイソトープ総合センター 久下裕司教授，大 阪薬科大学 天滿 敬教授, 岡山大学大学院医歯薬 学総合研究科 上田真史教授, 京都薬科大学 木村寛 之准教授, 京都大学再生医科学研究所 東 高志博 士, 中井隆介博士, 京都大学大学院情報学研究科 楢崎美智子博士に深く感謝申し上げます。さらに, 本研究の遂行にあたり多大なる貢献を頂きました金 崎健吾博士，工藤 喬博士，丁 寧博士，上端純子 修士，金田侑子学士を始めとする京都大学大学院薬 学研究科病態機能分析学分野の教室員一同, キヤノ ン株式会社の共同研究者の皆様に感謝申し上げま す。また，本稿の一部は，神戸薬科大学にて行われ た研究成果であり, 神戸薬科大学 向 高弘教授, 高橋勝史学士並びに教室員一同に心より感謝申し上 げます。なお，これらの研究は，文部科学省科学研 究費補助金，文部科学省特別経費 (プロジェクト分) 事業，新エネルギー・産業技術総合開発機構研究開 発事業, 島津科学技術振興財団, 武田科学振興財 団，上原記念生命科学財団の援助の下に実施された ものであり，併せて感謝致します，最後に，私の研 究活動を常に支え続けてくれている家族に感謝致し ます。

\section{利益相反＼cjkstart開示すべき利益相反はない.}

\section{REFERENCES}

1) Ding H., Wu F., Theranostics, 2, 1040-1053 (2012)

2) Kanazaki K., Sano K., Makino A., Yamauchi F., Takahashi A., Homma T., Ono M., Saji H., J. Control. Release, 226, 115-123 (2016).

3) Kanazaki K., Sano K., Makino A., Homma T., Ono M., Saji H., Sci. Rep., 6, 33798 (2016)

4) Sano K., Ohashi M., Kanazaki K., Makino A., Ding N., Deguchi J., Kanada Y., Ono M., Saji H., Bioconjug. Chem., 28, 1024-1030 (2017).

5) Kanazaki K., Sano K., Makino A., Takahashi A., Deguchi J., Ohashi M., Temma T., Ono M., Saji H., J. Biomed. Opt., 19, 96002 (2014)

6) Ku G., Wang L. V., Opt. Lett., 30, 507-509 (2005).

7) Ntziachristos V., Nat. Methods, 7, 603-614 (2010) .

8) Temma T., Sano K., Kuge Y., Kamihashi J., Takai N., Ogawa Y., Saji H., Biol. Pharm. Bull., 32, 1272-1277 (2009).

9) Sano K., Temma T., Kuge Y., Kudo T., Kamihashi J., Zhao S., Saji H., Biol. Pharm. Bull., 33, 1589-1595 (2010).

10) Sano K., Temma T., Azuma T., Nakai R., Narazaki M., Kuge Y., Saji H., Mol. Imaging Biol., 13, 1196-1203 (2011).

11) Hruby M., Filippov S. K., Panek J., Novakova M., Mackova H., Kucka J., Vetvicka D., Ulbrich K., Macromol. Biosci., 10, 916-924 (2010)

12) Sano K., Kanada Y., Takahashi K., Ding N., Kanazaki K., Mukai T., Ono M., Saji H., Mol. Pharm., 15, 3997-4003 (2018).

13) Sano K., Bao L., Suzuno N., Kannaka K., Yamasaki T., Munekane M., Mukai T., ACS Appl. Polym. Mater., 1, 953-958 (2019). 